\title{
Toxicon
}

March 2018, Volume 144, Pages 14-22

http://dx.doi.org/10.1016/i.toxicon.2017.12.050

http://archimer.ifremer.fr/doc/00416/52789/

(c) 2018 Elsevier Ltd. All rights reserved

\section{Sources of paralytic shellfish toxin accumulation variability in the Pacific oyster Crassostrea gigas}

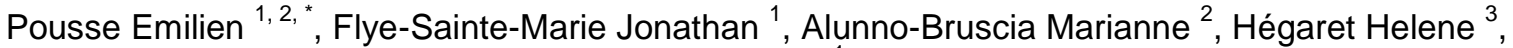 \\ Jean Fred ${ }^{1}$
}

${ }^{1}$ Université de Bretagne Occidentale (UBO), UMR 6539 LEMAR, IUEM, Technopôle Brest-Iroise, Rue Dumont d'Urville, 29280 Plouzané, France

2 Ifremer, UMR 6539 LEMAR, 11 presqu'île du Vivier, 29840 Argenton-en-Landunvez, France

*Corresponding author : Emilien Pousse, email address : pousseemilien@hotmail.fr

\begin{abstract}
:
This study was designed to assess the contribution of feeding behavior to inter-individual variability of paralytic shellfish toxin (PST) accumulation in the Pacific oyster Crassostrea gigas. For this purpose 42 oysters were exposed for 2 days to non-toxic algae and then for 2 other days to the PST producer Alexandrium minutum. Individual clearance rate (CR) of oysters was continuously monitored over the 4 days using an ecophysiological measurement system. Comparison of CR values when exposed to toxic and non toxic algae allowed to estimate a clearance rate inhibition index (CRII). Toxin concentration of oysters was quantified at the end of the experiment. These data allowed to estimate the toxin accumulation efficiency (TAE) as the ratio of toxin accumulated on toxin consumed. Changes of clearance rate during the experiment indicated that all individuals stopped feeding immediately after being exposed to $A$. minutum for at least $7 \mathrm{~h}$. This fast response likely corresponded to a behavioral mechanism of avoidance rather to a toxin-induced response. Individuals also showed high intervariability in their recovery of filtration after this period. Most of the inter-individual variability (78\%) in PST accumulation in $C$. gigas could be explained by the consumption of $A$. minutum cells, thus emphasizing the importance of the feeding behavior in accumulation. Based on the toxin concentration in their tissues, oysters were clustered in 3 groups showing contrasted patterns of PST accumulation: the high accumulation group was characterized by high feeding rates both on non-toxic and toxic diet and subsequently a low CRII and high TAE. Inversely, the low accumulation group was characterized by low filtration rates, high CRII and low TAE. Both filtration capacity and sensitivity of oysters to toxins may account for the differences in their accumulation. The contribution of TAE in PST accumulation is discussed and might result from differences in assimilation and detoxification abilities among individuals.
\end{abstract}




\section{Highlights}

- Facing exposure to $A$. minutum, individual clearance rates of oysters were measured. Algal consumption explains variability in paralytic shellfish toxin accumulation. Three phenotypes were identified on the basis of their accumulation potential. Phenotypes differed in their feeding rates. Phenotypes also differed in their sensitivity to toxins and accumulation efficiency.

Keywords : Alexandrium minutum, Paralytic shellfish poisoning, Accumulation, Clearance rate, Feeding behavior, Pacific oyster 
Historically, the French oyster culture has faced successive crises that threatened the cultured species and thus the industry (Buestel et al., 2009). The Pacific oyster, Crassostrea gigas was introduced in the 1970s from Japan and Canada into French farming areas to allow the conservation of oyster production (Grizel and Héral, 1991). Following its import, C. gigas became the most cultivated bivalve in France, but also worldwide (i.e. 4.8 millions of tons worldwide in 2013, FAO, 2015). Oyster aquaculture, however, is vulnerable to global warming (Rahel and Olden, 2008) and other associates phenomena such as disease epidemics (Goulletquer et al., 1998; Petton et al., 2015), biological invasions (Stachowicz et al., 2002) or harmful algal blooms (HAB; Moore et al., 2008).

The increasing number of HAB occurrences (Van Dolah, 2000; Anderson et al., 2002) has recently been related to warming of Atlantic and Pacific oceans (Gobler et al., 2017). These events can be responsible for amnesic, neurotoxic, diarrhetic or paralytic shellfish poisoning (PSP), among others, thus raising sanitary, social and economic problems. In 2005, total annual costs of HAB were estimated to ca. 813 million \$ for Europe (Hoagland and Scatasta, 2006). Amongst dinoflagellates, the ubiquitous and hazardous genus Alexandrium can produce saxitoxin (STX; Persich et al., 2006; Anderson et al., 2012), and other potent paralytic shellfish toxins (PST) derivatives from STX. By accumulating toxins in their tissues, filter-feeders can become toxic for consumers (animals or humans, e.g. Bond and Medcof, 1958; Nisbet, 1983; Kwong et al., 2006). PSP in humans can induce numbness, tingling up to paralysis or even death (McFarren et al., 1961).

Low environmental concentrations in Alexandrium minutum can result in significant accumulation. For instance, environmental concentrations ranging between 9 and 140 cells $\mathrm{mL}^{-1}$ during three weeks were sufficient to induce paralytic shellfish toxin accumulation in $C$. gigas above the sanitary threshold (80 $\mu \mathrm{g}$ equivalent STX $100 \mathrm{~g}^{-1}$; REPHY, 2015) in the bay of Brest during summer 2015. In France, a concentration of Alexandrium sp. in seawater above the alert threshold $\left(10\right.$ cells $\left.\mathrm{mL}^{-1}\right)$ triggers the quantification of toxin concentration within bivalve tissues which results determine if shellfish harvest has to be closed by

\footnotetext{
*Email: pousseemilien@ @otmail.fr
} 
the legal authorities. This decision may sometimes be controversial since the toxin accumulation can vary with the site (Cembella et al., 1994), the bivalve species (Sagou et al., 2005), the individual and/or the organ where toxins are quantified (Kwong et al., 2006). Individual size, seston concentration and its volumespecific toxin concentration have been identified as main sources of variability in mussel PST accumulation (Mytilus galloprovincialis ; Moroño et al., 2001). Many studies compared behavior and physiology of different bivalve species to explain inter-species variability (Marsden and Shumway, 1993; Contreras et al., 2012; Marsden et al., 2015). Bricelj et al. (1996) showed that the feeding response of different bivalve species was correlated to the animal sensitivity to toxins and to the algal toxicity. Bivalve sensitivity to toxins was defined after observations of neurological (Twarog et al., 1972), physiological (Bricelj et al., 1990; Contreras et al., 2012), and behavioral responses (Shumway and Cucci, 1987; Gainey et al., 1988; Bricelj et al., 1996). Under similar experimental conditions PST concentrations in bivalve tissues were shown to vary among individuals by a factor up to 5000 (Mat et al., 2013), indicating a huge inter-individual variability. Nevertheless the mechanisms explaining this variability remained poorly understood making tricky any prediction of accumulated toxins with modeling approach. Oysters exposed to A. minutum (Bougrier et al., 2003) showed a positive relationship between feeding time activity (percent of total time spent in active filtration) and their toxin concentration. These results suggest that the variability in toxin accumulation might also be explained by the variability in feeding behavior of $C$. gigas. In this context, it can be hypothesized that (1) inter-individual variability in the clearance rate while feeding on toxic algae (i.e. filtration capacity) is responsible for the variability in toxin accumulation. Nevertheless, Haberkorn et al. (2011) was not able to show any link between oyster valve behavior during acclimation (oyster fed non-toxic algae) and concentration of toxins accumulated after a subsequent exposure, but rather showed that during the exposure to $A$. minutum, some oysters tend to increase their valve-opening time and strongly accumulate (also observed in Mat et al., in prep.). Thus an additional hypothesis is that (2) behavioral inter-individual variability facing an exposure to A. minutum is responsible for inter-individual variability in toxin accumulation. Indeed, it can be hypothesized that when facing an exposure to A. minutum some oysters will reduce their clearance rate and will accumulate less toxin, while others will maintain filtration activity and will accumulate more. The present study was designed to further explore the relationship between feeding behavior and toxin accumulation and to test $i$ ) if there is a link between feeding on non-toxic algae prior $A$. minutum exposure and PST accumulation, ii) how much feeding on toxic algae contributes to the variability in PST accumulation. For this purpose oysters' clearance rate fed 2 days on non-toxic algae and then exposed to A. minutum for 2 
more days were monitored.

\section{Material and methods}

\subsection{Biological material}

Oysters. Ten-months old diploid $C$. gigas oysters $(\mathrm{N}=42)$ (shell length $=32.7 \mathrm{~mm} \pm \mathrm{SD} 3.1$; total wet mass $=4.3 \mathrm{~g} \pm \mathrm{SD} 0.7$; wet flesh mass $=1.0 \mathrm{~g} \pm \mathrm{SD} 0.2$ and $0.2 \mathrm{~g}$ in dry flesh mass \pm SD 0.05 ) were used in this experiment. They originated from a cohort of specific-pathogen free oysters produced and reared according to a standardized protocol (Petton et al., 2013, 2015) in Ifremer experimental facilities at Argenton (Brittany, France). They were born in August 2014 from 60 wild broodstock genitors collected in Marennes-Oléron (see Petton et al., 2013). During the whole rearing cycle, oysters were fed ad libitum on a mixture of Tisochrysis lutea and Chaetoceros muelleri and were never exposed to any harmful algal bloom.

Algae cultures. T. lutea (CCAP 927/14) and C. muelleri (CCAP 1010/3) were used as the main non-toxic food for oysters. They were cultured with continuous light in separated 300-L cylinders enriched with Conway medium (Walne et al., 1970), and with silicium for C. muelleri. The dinoflagellate Alexandrium minutum (RCC4876, strain Daoulas 1257, isolated in the bay of Brest) was used as the paralytic shellfish toxin (PST) producer. This strain produced only PST toxins, i.e. no extracellular compounds responsible for any allelopathic effects (Castrec et al, in prep.), at a concentration of $52.8 \mathrm{fg}^{\mathrm{STX}}$ equivalent cell ${ }^{-1}$ (quantified by HPLC at Ifremer Nantes "Laboratoire des phycotoxines", according to Guéguen et al., 2011, protocol). This strain of A. minutum was cultured at $21^{\circ} \mathrm{C}$ in $300-\mathrm{L}$ cylinders of filtered seawater enriched with L1 medium (Guillard and Hargraves, 1993) under continuous light. The culture of A. minutum was sampled during the exponential growth phase and diluted for further exposure of oysters to PST. Algal concentrations of the 3 algal species were monitored daily using a Beckman Coulter Multisizer 3 and expressed in number of cells per milliliter and cell volume $\left(\mu \mathrm{m}^{3}\right)$ per milliliter .

\subsection{Experimental setup and data collection}

Ecophysiological measurement system. The COSA measurement system (fully described in Aguirre-Velarde et al., 2018) allowed to monitor individual clearance rates (Fig. 1) and was similar to previous automatic devices (Savina and Pouvreau, 2004; Flye-Sainte-Marie et al., 2007). The system was composed of 8 identical 0.54-L flow-through acrylic chambers supplied with algal mix pumped from a mixing tank. Each chamber 


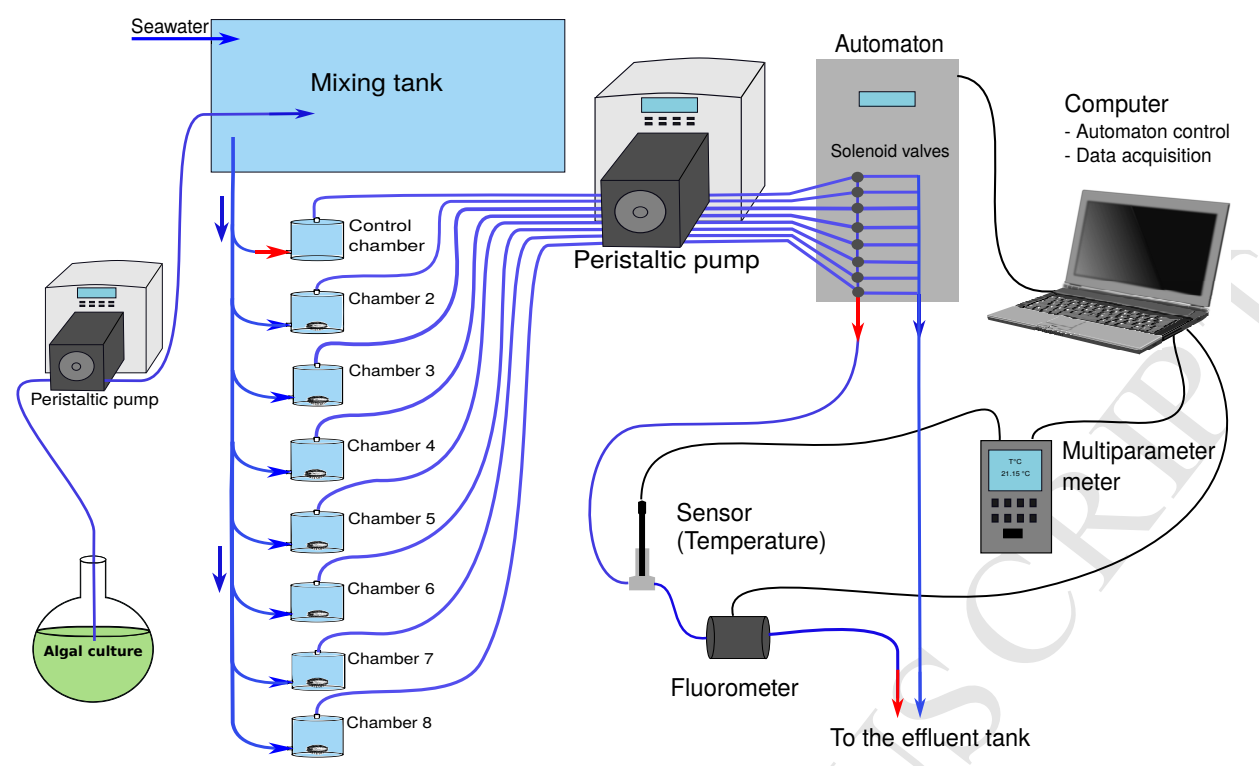

Figure 1: The COSA measurement system. Blue lines indicate the hydraulic circuit and black lines data connections. The control chamber (without oyster) is used as a reference of seawater passing through all chambers. Chambers 2 to 8 contain one oyster each. A peristaltic pump allows the circulation of the water throughout each chamber at a constant flow rate. The computer-controlled automaton controls the water outflowing from any chamber either to a measurement circuit (temperature sensor and fluorometer) or directly to the effluent tank. Chambers 2 to 8 are measured sequentially for 15 min every $3.5 \mathrm{~h}$; between each measurement on a chamber containing an oyster the control chamber is measured for 15 min. A computer allows to control the automaton, log and visualize in real-time acquired data.

contained one single oyster, except one empty control chamber (Figure 1). Flow rate in the chamber was adjusted to $40 \mathrm{~mL} \mathrm{~min}^{-1}$ by means of 2 peristaltic pumps (Masterflex L/S 7551, Cole Parmer, USA). The seawater temperature $\left({ }^{\circ} \mathrm{C}\right)$ and the fluorescence (FFU) were measured for 15 minutes in the outflow of each chamber by a WTW multiparameter meter (WTW Multi 3430) and a fluorometer (WETstar cholorophyll, WETLABS, Philomat, USA). Calibration lines obtained from cell counts allowed to recalculate microalgal concentrations from fluorescence. These instruments were connected to a computer that allowed the visualization and acquisition of high frequency time series data. The fluorescence of the water outflowing from chambers 2 to 8 (containing oysters) was monitored sequentially for 15-min cycle; between each chamber containing an oyster, the control chamber (chamber 1) was also measured for $15 \mathrm{~min}$. This protocol allowed the monitoring of each chamber every $3.5 \mathrm{~h}$. All water effluents were treated with chlorine.

Experimental design. During 4 days, 7 oysters were monitored individually in the flow-through chambers under controlled conditions. Seawater and ambient air temperatures were maintained at $21^{\circ} \mathrm{C}$. During day 1 
and day 2, oysters were fed on a 50/50 algal mixture of $T$. lutea and C. muelleri (Tiso/Chaeto). The exposure to A. minutum was performed on day 3 and day 4 . This trial was repeated 6 times so that a total of 42 oysters were monitored over the whole experiment. The concentration of Tiso/Chaeto mixture was adjusted as a function of the fluorescence in the control chamber thus resulting in algae concentration ranging between 16000 and 24000 cells $\mathrm{mL}^{-1}$ due to the variability of fluorescence properties of the algae culture. For each exposure trial, A. minutum was distributed at different levels of concentration ranging from a mean of 650 cells $\mathrm{mL}^{-1}$ for the lowest to 1800 cells $\mathrm{mL}^{-1}$ for the highest exposure concentration.

The system was stopped daily during two hours for cleaning to prevent the development of a biofilm within the circuit. Oysters were removed from their chambers and maintained in $1 \mu \mathrm{m}$ filtered seawater. The entire circuit (chambers included) was washed with a stabilized mixture of peracetic acid and hydrogen peroxide (Hydrogent) and rinsed with hot freshwater and then with filtered seawater.

Final biometry and toxin quantification. At the end of each 4-days trial, oyster tissues were dissected, weighed (wet mass, $\mathrm{g}$ ) and stored at $-80^{\circ} \mathrm{C}$ until toxin quantification.

PST were quantified individually in total oyster body tissues using ELISA PSP kit developed by Abraxis (see methods in Lassudrie et al., 2015a,b). For this purpose, oyster tissues were mixed (1:1, w:v) in 0.1 $\mathrm{M} \mathrm{HCl}$ solution, grounded (Fastprep-24 5G homogenizer) and boiled for 5 minutes at $100^{\circ} \mathrm{C}$ in order to acid-hydrolyse PST analogs into saxitoxins (STX). The samples were then disposed in the Abraxis ELISA PSP kit and toxin concentrations were quantified by spectrophotometry and expressed in $\mu \mathrm{g}$ of STX for 100 $\mathrm{g}$ of total flesh mass.

\subsection{Data analysis}

Clearance rates. Individual clearance rates $\left(\mathrm{CR}_{\text {oyst }}, \mathrm{L} \mathrm{h}^{-1} \mathrm{ind}^{-1}\right)$ corresponding to the volume of exhaled water cleared of particles per unit time, were calculated from the fluorescence data recorded during the last 7 minutes of each measurement period (in order to allow a full water renewal on the sensors). According to Hildreth and Crisp (1976) formula:

$$
C R_{\text {oyst }}=F_{R} \frac{\text { Fluo }_{\text {cont }}-\text { Fluo oyst }_{\text {of }}}{\text { Fluo oyst }^{\text {on }}}
$$

where, $F_{R}$ is the flowrate throughout the chamber $\left(\mathrm{L} \mathrm{h}^{-1}\right), F l u o_{\text {cont }}$ the average florescence of the control chamber measured before and after the chamber, and Fluo $_{\text {oyst }}$ the average fluorescence of chamber 2 to 8 containing one oyster each. 
In order to correct these rates from variations in individual size between chambers, individual clearance rates were standardized to a standard size of $1 \mathrm{~g}$ in flesh wet mass using Bayne et al. (1987) formula:

$$
C R_{s}=\left(\frac{W_{s}}{W_{\text {oyst }}}\right)^{b} \times C R_{\text {oyst }}
$$

where $C R_{S}$ was the clearance rate corrected for an individual of a standard mass $W_{s}$ (i.e. $1 \mathrm{~g}$ of wet mass), $W_{\text {oyst }}$ the wet mass of the monitored oyster, $C R_{\text {oyst }}$ the measured clearance rate of the oyster and $b$ was the allometric coefficient equal to $\frac{2}{3}$ according to Pouvreau et al. (1999).

Clearance rate inhibition index. For each individual, standardized clearance rates measured during days 1 and $2\left(C R_{\text {Snon toxic }}\right)$ and standardized clearance rates at day 4 with toxic algae $\left(C R_{\text {Stoxic }}\right)$ were used to compute a clearance rate inhibition index $(C R I I)$ allowing to quantify the inhibition of clearance rate due to $A$. minutum. It was calculated as $C R I I=1-\frac{C R_{\text {Stoxic }}}{C R_{\text {Snon toxic }}}$

Statistics and clustering. Statistical analyses were performed using the R software (R Core Team, 2016). Type II linear regressions with ranged major axis method were applied to adjust linear relations between the number of algal cells consumed and the toxin concentration (two variables measured with error) by using the R package "lmodel2" (Legendre, 2014).

Because the concentration of $A$. minutum varied among experiments, the 42 oysters were clustered according to their ratio between the toxin concentration after exposure and the quantity of $A$. minutum cells delivered during exposure. Three accumulation groups could be easily distinguished on the basis of this ratio, thus corroborating previous observations (Boullot, 2017; Mat et al., in prep.). A hierarchical clustering function was applied on this ratio with the Ward's method to segregate individuals into three groups.

In order to compare individual CR prior and during the exposure to A. minutum among the 3 clusters, linear mixed-effect models were adjusted. Tukey post-hoc tests were applied to distinguish groups.

\section{Results}

\subsection{Toxin accumulation in oyster tissues}

After the 2-d exposure to A. minutum, all oysters accumulated toxins in their tissues at concentrations varying between 6 and $173 \mu \mathrm{g}$ of STX per $100 \mathrm{~g}$ of wet flesh. Among them, half of the individuals exhibited toxins above the sanitary threshold of $80 \mu \mathrm{g}$ of STX per $100 \mathrm{~g}$ of wet flesh and no mortality was observed. 
The ratio of the lowest to the highest concentration of toxins within each 4-d trial (i.e. for 7 oysters) varied from 2.1 to 8.5 , indicating a strong inter-individual variability in toxin accumulation. In most experiments, three accumulation groups were easily distinguishable which corroborated previous observations (Boullot, 2017; Mat et al., in prep.). Based on the ratio of the concentration of toxins to the number of A. minutum cells distributed, the 42 oysters were clustered into 3 groups using a hierarchical clustering function. This allowed to assign 10 oysters (24\%), 21 oysters (50\%) and 11 oysters (26\%), respectively to the low, intermediate and high toxin accumulation groups.

\subsection{Temporal evolution of oyster clearance rates}

Standardized clearance rate measurements indicated that oyster filtration activity almost stopped just after the exposure to A. minutum for a period of $\approx 7 \mathrm{~h}$ (Fig. 2). Then a recovery was observed for some individuals, this tendency being more visible $24 \mathrm{~h}$ after the beginning of the exposure. Nevertheless, filtration activity did not recover to values observed with non-toxic algae. Pseudo-faeces production was only exceptionally observed during the experiments.

When fed on non-toxic algae (days 1 and 2$)$, the average $\mathrm{CR}$ for a standard oyster of $1 \mathrm{~g}\left(C R_{\text {Snon-toxic }}\right)$ was significantly higher for the high accumulation group compared to the low one. But no significant differences were observed between the low and intermediate groups nor between the high and intermediate groups (Tab. 1). After the early phase of CR inhibition, at the beginning of the exposure phase to $A$. minutum, mean individual standardized CR differed significantly among the 3 accumulation groups, with respectively $0.33 \mathrm{~L} \mathrm{~h}^{-1}, 1.06 \mathrm{~L} \mathrm{~h}^{-1}$ and $2.24 \mathrm{~L} \mathrm{~h}^{-1}$ for low, intermediate and high accumulation groups (Tab. 1).

Table 1: Results of the Tukey test performed on linear mixed-effects models in order to compare clearance rates of oysters before (day 2 only) and during (day 4 only) exposure to A. minutum for the three accumulation clusters ( ${ }^{*}$, p-values $<0.05$ and ${ }^{* * *}$ p-values $<0.001)$.

\begin{tabular}{|c|c|c|c|c|c|c|c|c|}
\hline \multirow{2}{*}{ Accumulation clusters } & \multicolumn{4}{|c|}{ Before exposure (day 2) } & \multicolumn{4}{|c|}{ During exposure (day 4) } \\
\hline & Estimate & Std. Error & $\mathrm{z}$ value & $\mathrm{p}$-value & Estimate & Std. Error & $\mathrm{z}$ value & $\mathrm{p}$-value \\
\hline Low - Intermediate & 0.7154 & 0.2760 & 2.592 & $0.028^{*}$ & 0.7232 & 0.2494 & 2.899 & $0.011^{*}$ \\
\hline Low - High & 1.3546 & 0.3241 & 4.179 & $<10^{-4 * * *}$ & 1.8765 & 0.2927 & 6.412 & $<10^{-9 * * *}$ \\
\hline Intermediate - High & 0.6392 & 0.2852 & 2.242 & 0.075 & 1.1533 & 0.2583 & 4.465 & $<10^{-4 * * *}$ \\
\hline
\end{tabular}




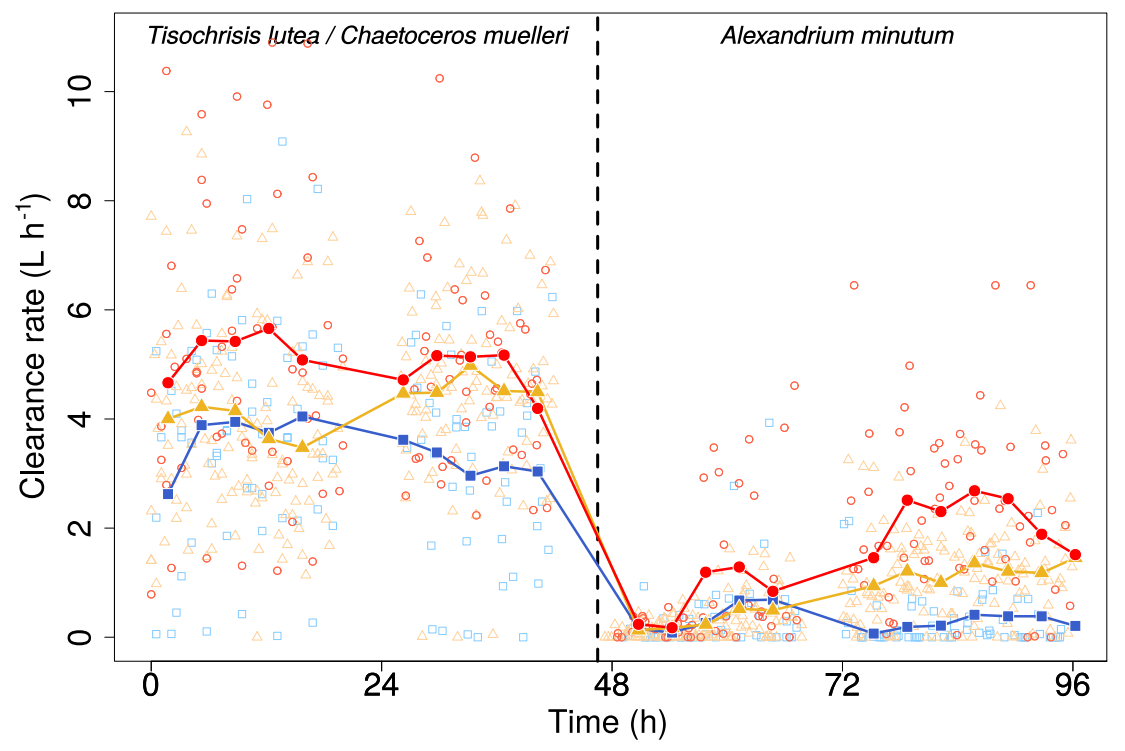

Figure 2: Evolution of standardized clearance rates over the 4 experimental days for all experiments. The first 2 days, oysters were exposed to a mix of T. lutea and C. muelleri, followed by a 2-day exposure to A. minutum. Empty markers correspond to all individual measurements performed on: $\square$ the low accumulation cluster, $\Delta$ the intermediate accumulation cluster and $\circ$ the high accumulation cluster. Filled markers correspond to the average values for each acquisition cycle ( $3.5 \mathrm{~h})$ of each accumulation cluster: $\bullet$ low, $\Delta$ intermediate and $\bullet$ high accumulation clusters.

\subsection{Inhibition of oyster clearance rate when exposed to A. minutum}

There was a significant inverse relationship between clearance rate inhibition index $(C R I I)$ and the concentration of toxins in oyster tissues (Spearman's rho=-0.69, p-value $=1.1610^{-6}$; Fig. 3). CRII differed significantly between accumulation groups (Wilcoxon test, $\mathrm{p}$-values $<0.05$ ) with mean values of $0.86,0.71$ and 0.53 respectively in the low, intermediate and high accumulation groups.

\subsection{Relationship between oyster algal consumption and toxin accumulation}

Algal consumption rates (cell $\mathrm{g}^{-1} \mathrm{~d}^{-1}$ ) were calculated from unstandardized clearance rates, algal concentrations and individual oyster wet mass and allowed to take into account the different algal concentrations delivered. The correlation between these values and the final toxin concentration was thus evaluated (Fig. 4 and 5). A strong and significant relationship could be observed between the total number of A. minutum cells consumed during the exposure and the final toxin concentration with a $\mathrm{R}^{2}$ of 0.78 (Fig. 4). Daily relationships are shown in Figure 5. 


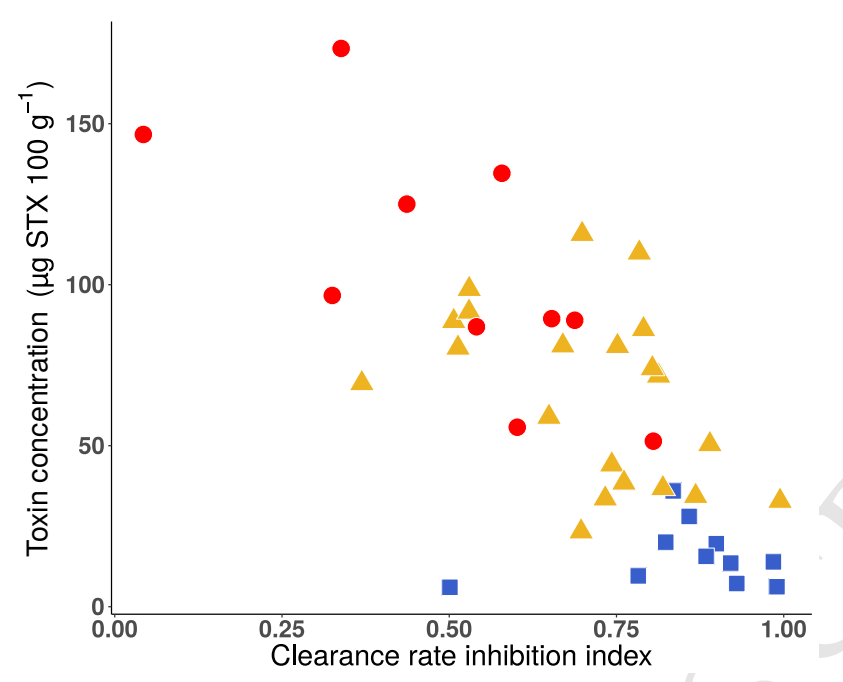

Figure 3: Individual clearance rate inhibition index $(C R I I)$ as a function of final toxin accumulation. Symbols refer to the different accumulation groups: - low, $\triangle$ intermediate and $\bullet$ high accumulation clusters. Spearman's rho was calculated from these data resulting in an inverse correlation equal to $-0.69\left(\mathrm{p}\right.$-value $\left.=1.1510^{-6}\right)$.

No correlation was found between the toxin concentration in oyster tissues at day 4 and their algae consumption at days 1 and 2 (Fig. 5 a and b), suggesting that the filtration of oysters on non-toxic algae was

likely not related to their accumulation capacity. Conversely, the toxin concentrations in oyster tissues were significantly correlated with the number of cells they consumed on day $3\left(R^{2}=0.29\right)$ and on day $4\left(R^{2}=0.81\right)$ (Fig. $5 \mathrm{c}$ and d). This indicated that the number of cells consumed by oysters on the second (and last) day of exposure to A. minutum contributed to the majority of the toxins that have been accumulated in oyster tissues.

\subsection{Oyster tissues toxin concentration and toxins consumed}

Toxin amount consumed by oysters was estimated on the basis of the number of $A$. minutum cells consumed and the STX content of each A. minutum cell (52.8 fg STX eq. cell ${ }^{-1}$, see section 2.1). The ratio between the final toxin content and the amount of toxin consumed was calculated for each individual and compared between accumulation clusters (Fig. 6). Such a ratio provides an indication of the toxin accumulation efficiency (TAE; see e.g. Bougrier et al., 2003; Mafra et al., 2010), which may depend on various processes i.e. pre-ingestion selection, toxin assimilation but also toxin depuration. This ratio significantly differed between clusters (Wilcoxon tests; $\mathrm{p}<0.01$ ). The low accumulation cluster had the lowest ratio as the high accumulation cluster had the highest. 


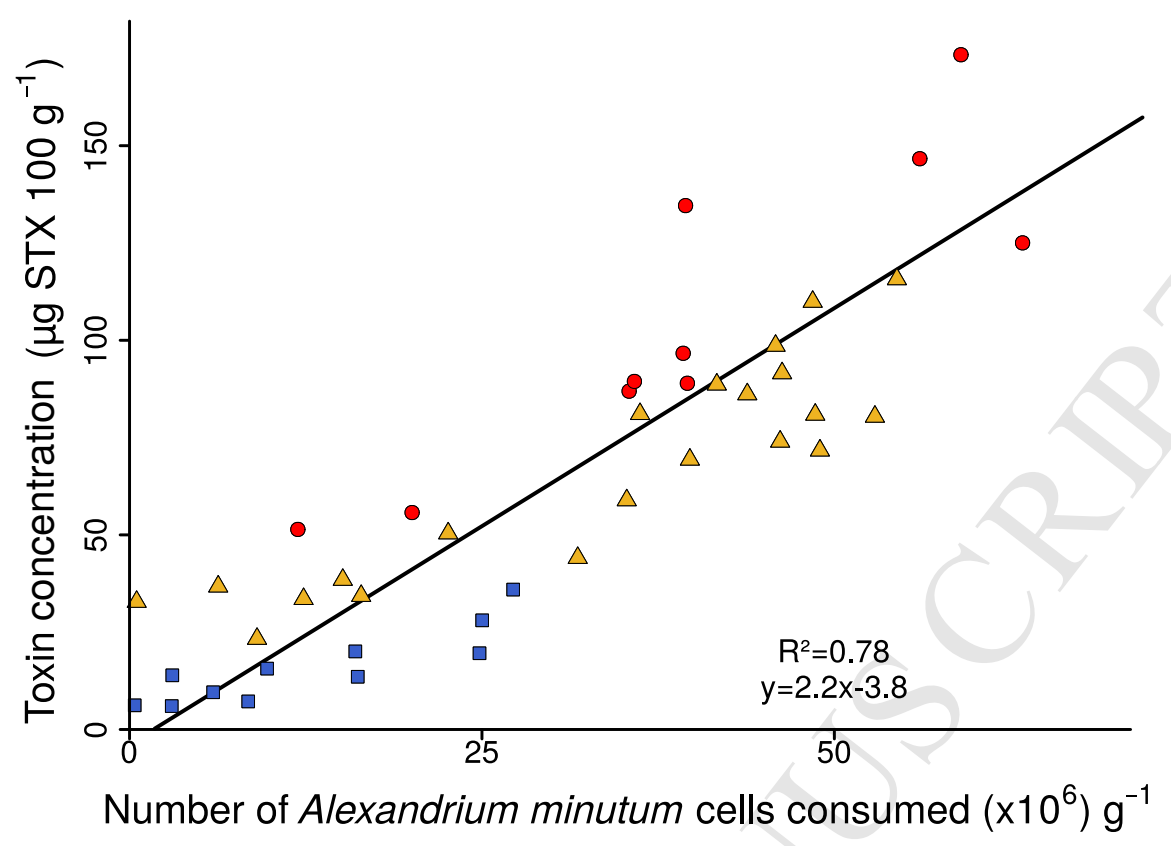

Figure 4: Individual toxin concentration in oyster tissues at day $4\left(\mu \mathrm{g} \mathrm{STX} 100 \mathrm{~g}^{-1}\right)$ against the cumulated number of A. minutum cells consumed by oysters $\left(\mathrm{g}^{-1}\right.$ of wet mass) over all trials of the experiment. The line corresponds to the adjusted type II regression. Symbols refer to the different accumulation clusters: • low, $\Delta$ intermediate and $\bullet$ high accumulation clusters.

\section{Discussion}

4.1. Feeding behavior during an exposure to A. minutum drives toxin accumulation

Previous results clearly emphasize the importance of inter-individual variability in toxin accumulation by $C$. gigas. Laboratory experiments showed that oysters exposed to similar concentration of A. minutum exhibited a variability in toxin accumulation up to a factor 5000 (Mat et al., 2013). The aim of this study was to test if feeding behavior could be responsible for variability in toxin accumulation as hypothesized by Bougrier et al. (2003) and Haberkorn et al. (2011). Our results emphasized a high inter-individual variability in clearance rates of both non-toxic and toxic algae although all individuals used for this experiment came from the same cohort and were reared under the same conditions. Similar to Bougrier et al. (2003) a close correlation between the number of A. minutum cells consumed by oysters and the final concentration of toxin in their tissues was observed (Fig. 4). Our results thus showed that inter-individual variability in harmful algal consumption during an exposure to A. minutum explained $78 \%$ of the variability in final toxin accumulation. 

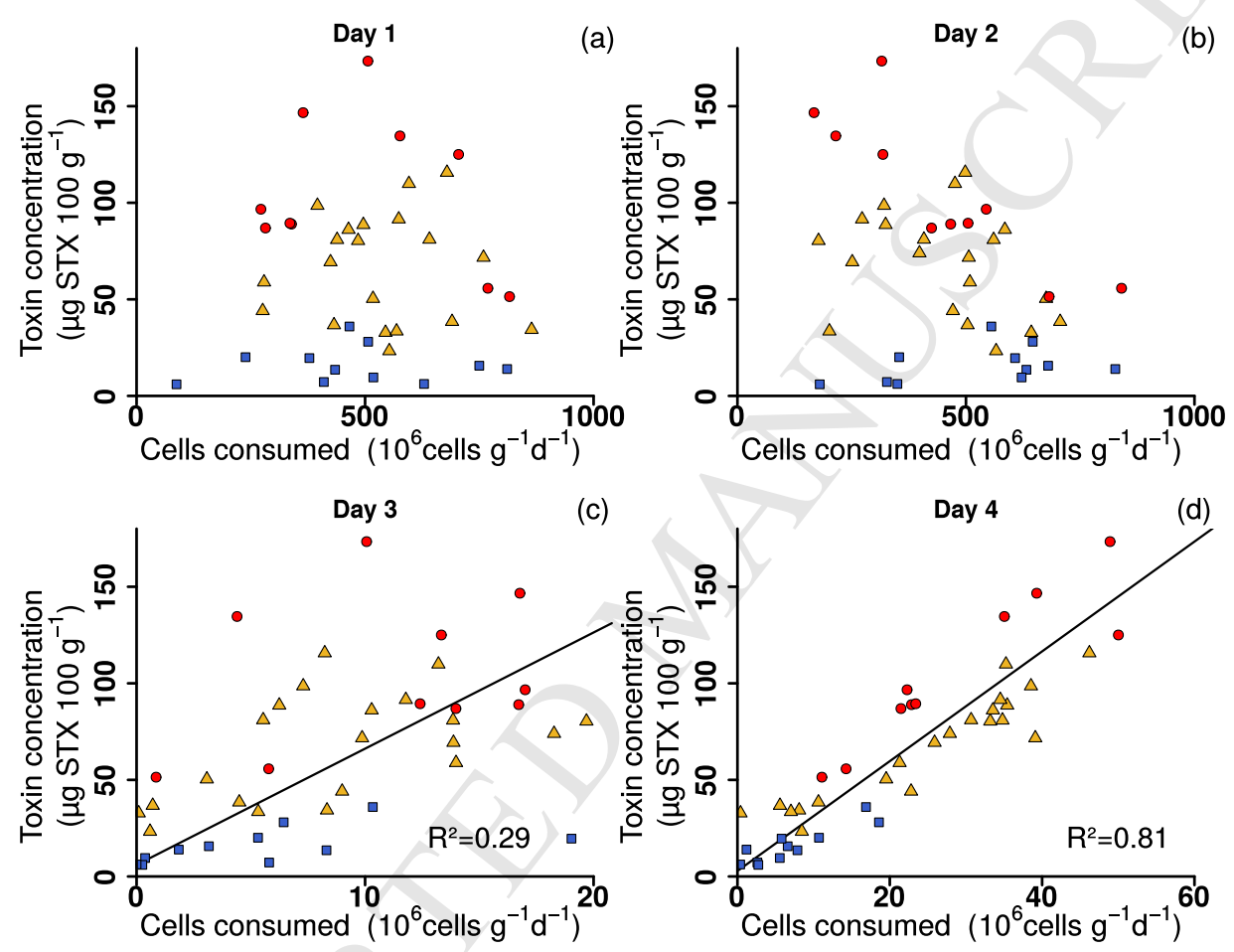

Figure 5: Individual toxin concentration in oyster tissues at the end of the exposure (day 4, $\mu \mathrm{g}$ STX $100 \mathrm{~g}^{-1}$ ) against the daily algae consumption of oysters (number of cells $\mathrm{g}^{-1}$ ) for all trials. Lines indicate the adjusted type II regression models (when significant). Oysters were fed T. lutea and C. muelleri during days 1 (a) and 2 (b) and A. minutum during days 3 (c) and 4 (d). Symbols refer to the different accumulation clusters: • low, $\Delta$ intermediate and $\bullet$ high accumulation clusters. 


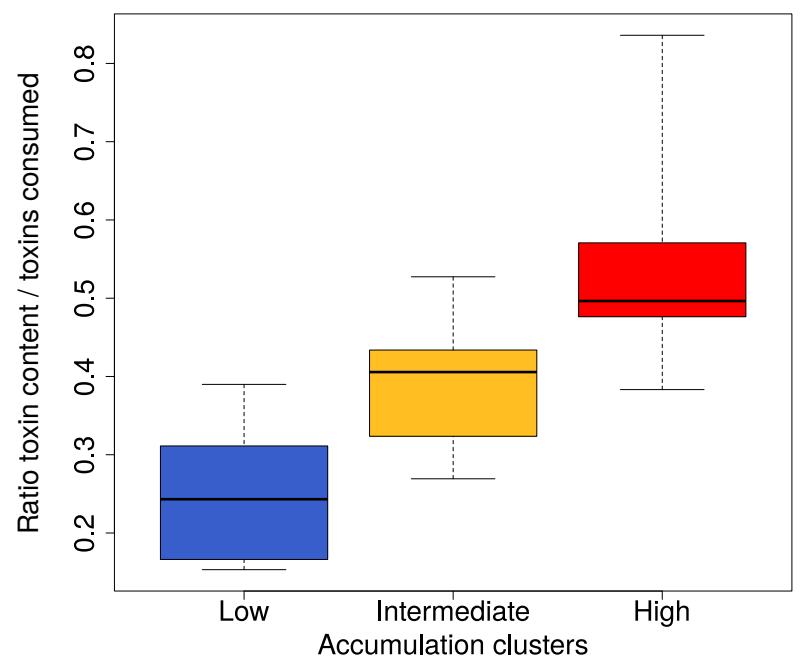

Figure 6: Ratio between final toxin content and toxins consumed for the three accumulation clusters. Low, intermediate and high accumulation clusters are composed of 10, 19 and 9 oysters respectively. Four aberrant values were removed from the dataset. Horizontal lines correspond to the median, boxes to $50 \%$ of the variability and error bars to the minimum and maximum values.

\subsection{Initial feeding response to A. minutum exposure}

Despite the high inter-individual variability in $C R_{s}$, the 42 individuals exhibited the same reaction to A. minutum exposure: they all reduced or even stopped their filtration activity for at least 7 hours (Fig. 2). This reduction was followed by a partial recovery during which inter-individual variability was high. Such a two-phase response has already been described in C. gigas exposed to Alexandrium catenella (Dupuy and Sparks, 1968).

Although not observed in all species (Leverone et al., 2007; Hegaret et al., 2007; Contreras et al., 2012) this inhibition in feeding activity immediately after an exposure to PSP-causing dinoflagellates seems to be a general pattern in the genius Crassostrea (e.g. Shumway and Cucci, 1987; Gainey et al., 1988; Wildish et al., 1998; Laabir et al., 2007). Several mechanisms may explain this immediate initial response: a direct impact of the toxin on gills (Medler and Silverman, 2001) and muscles (Hégaret et al., 2007) decreasing filtration activity, or a behavioral inhibition of feeding activity allowing avoidance of poor quality or toxic seston (Lassus et al., 1999, 2004). The first hypothesis is unlikely because it would imply a delayed response (4-5 days in $C$. virginica exposed to PST; Hégaret et al., 2007), but a behavioral modification was rather immediate as also observed by Tran et al. (2010). A partial recovery of filtration occurred in most of the oysters (Fig. 3) after less than $24 \mathrm{~h}$ and oysters that accumulated more toxins were also those that filtrated 
more (Fig. 4). These two observations are additional elements against the toxin effect hypothesis. Wildish et al. (1998) did not observe any differences in short-term responses of $C$. gigas exposed to toxic and non-toxic Alexandrium sp. and also hypothesized that PSP toxins were not directly involved. A behavioral avoidance mechanism of oysters was the most plausible explanation in our experiment. Pre-ingestive sorting is a well known strategy to avoid low-quality particles (Ward et al., 1998; Mafra et al., 2009) but it is unlikely that this phenomenon occurred because (1) pseudo-faeces production was only exceptionally observed and (2) pseudo-faeces production does not imply reduction of clearance rate as observed. Under sub-optimal condition, bivalves can adapt the filtration activity by reducing valve gape, retracting mantle edge (see review in Jørgensen, 1996) decreasing ctenidia transport velocity (Ward et al., 2003). Facing a change in diet quality (size, shape, nutritive quality, species...) like shifting from forage algae to A. minutum it is likely that such a phenomenon occurs. Valve closure of oysters when exposed to Alexandrium sp. have been previously observed (Shumway et al., 1985; Tran et al., 2010).

\subsection{Mechanisms behind the behavioral variability of oysters in response to A. minutum}

One interesting observation is the high inter-individual variability in the recovery of filtration activity in the second phase of the exposure. The three accumulation clusters exhibited significantly different clearance rates on the second day of exposure to A. minutum (Fig. 2 ; Tab. 1). This high inter-individual variability is also emphasized by the highly variable clearance rate inhibition index (CRII) that ranges from close to 0 for oysters in the high accumulation cluster from close to 1 for oysters in the low accumulation cluster (Fig. 3). High clearance rate inhibition index values were inversely related to low toxin accumulation . Thus variability of the clearance rate inhibition in the reaction to A. minutum seems to play a major role in the variability of the toxin accumulation. In other words, when facing an exposure to A. minutum all oysters reduce their filtration activity, some less than others, thus leading to an important variability in toxin accumulation. This variability might be explained by two non-mutually exclusive hypotheses.

The first one would be that inter-individual variability in standardized clearance rate during exposure is linked to inter-individual variability in filtration capacity estimated as the standardized clearance rate on non-toxic algae. When fed non-toxic algae, individuals displayed variable levels of clearance rates (Fig. 2) that might be interpreted as phenotypic variability in filtration capacity. Our results show that the hierarchy of clearance rates of the different accumulation clusters remain identical before and during exposure. The level of feeding on non-toxic algae might thus constitute a first basis to predict the feeding response of 
oysters facing A. minutum. However the tendency is not that clear since non-toxic food consumed does not significantly explain the final toxin concentration (Fig. $5 \mathrm{a}$ and b). Variability in filtration capacity might contribute to the observed variability facing A. minutum nevertheless the relative reduction in clearance rate (CRII) observed is variable between individuals.

The second hypothesis would be that individuals present an inter-individual variability in their sensitivity facing A. minutum, either linked to behavioral differences facing A. minutum or linked to differences in sensitivity to the toxin itself. Interspecific differences in sensitivity, estimated through block of nerve action potential (Twarog et al., 1972), have been associated with differences in toxin accumulation: the most sensitive species tend to accumulate less (see review of Bricelj and Shumway, 1998). Such a pattern has also been observed at an intraspecific scale in Mya arenaria (Bricelj et al., 2005). Because a part of sensitivity to STX has been observed to have a genetic basis (sodium channel polymorphism; Kontis and Goldin, 1993; Bricelj et al., 1996), it might differ between individuals. It can be thus hypothesized that some individuals are more sensitive to the toxin, that their clearance rate is more inhibited and that they subsequently accumulate less toxins. Our results, however clearly show that within a single oyster population there is an important inter-individual variability in the level of inhibition of the clearance rate (at day 4) which is significantly linked to the toxin concentration (Fig. 3). The mechanisms behind the variability of clearance rate inhibition after recovery of feeding (day 4) remains to be identified.

\subsection{Toxin accumulation efficiency}

Toxin accumulation efficiency (TAE) is generally taken as [cumulative toxin ingested/ toxin incorporated in tissues] $\times 100$ and has been used for inter-species comparisons (see e.g. Bricelj et al., 1990; Bricelj and Shumway, 1998). Although our experimental design was different from the one of Bougrier et al. (2003) we found an average TAE of the same order of magnitude (35\% present study ; 20-23\% in Bougrier et al., 2003). Moreover, the mean TAE calculated before might be more likely close to $30 \%$ since the ELISA method used to measure the toxin concentration is known to overestimate with an approximate 1.2 factor compared to HPLC (Lassudrie, pers. comm.). These values are close to those obtained for Mercenaria mercenaria (35-40\%, Bricelj et al., 1991) or Pecten maximus (30\%, Bougrier et al., 2003) but lower than those observed for mussels (72\% to 96\% in Mytilus californianus, Dupuy and Sparks, 1968; 50\% in Perna viridis, Wisessang et al., 1991; 78\% in Mytilus edulis, Bricelj et al., 1990). Relating these values to Twarog et al. (1972)'s ranking of sensitivity to STX tends to indicate that species presenting a high TAE are less sensitive and, as discussed above, tend to accumulate more (Bricelj and Shumway, 1998). 
These results are the first ones to emphasize intra-specific variations of TAE, which significantly differed between accumulation clusters (Fig. 6). The high accumulation group had a TAE twice as high as the low accumulation one. Interpretation of the variations of TAE is not straightforward, because total toxin burden is the sum of toxin content of two compartments:(1) undigested toxins that remains in the digestive tract and (2) assimilated toxin within body tissues (Bricelj et al., 1990; Lassus et al., 2007). Variations of TAE may thus be linked to variations in inputs and/or outputs of these compartments. Because consumption was estimated from clearance rate, pseudo-feces production could affect the ingestion and thus the estimation of TAE; but it is unlikely because pseudo-feces production was only punctually observed. Lassus et al. (2007) modeled the PST accumulation kinetics in $C$. gigas in the Thau lagoon by taking into account two depuration ways: (1) a mechanical one, via the egestion of undigested toxins (called "excretion" in Lassus et al., 2007) which is a fast pathway and considered as the major one; (2) metabolic elimination (biotransformation; related to amonia excretion according to Navarro and Contreras, 2010) of assimilated toxins which is a slower and minor pathway.

Two mechanisms might explain the different observed values of TAE. Firstly, high TAE values might be associated with high food (and toxin) assimilation and therefore reducing the amount of egestable toxins. According to Lassus et al. (2007), these assimilated toxins would be less efficiently eliminated. Secondly, the metabolic elimination pathway could be saturated due to the high concentrations of toxins. Thus individuals with high concentrations of PST could reach a maximum toxin elimination rate and subsequently detoxify lower in relation to the amount of toxins. Further experimental work is needed to better understand the relative contribution of the assimilation and detoxification on the variations of TAE.

\subsection{Applications for aquaculture}

Further analyses on the three accumulation clusters would be needed to characterize if these differences in phenotype have a genetic basis. A heritable genetic basis of the accumulation of okadaic acid (another phycotoxin) has been shown in Mytilus galloprovincialis (Pino-Querido et al., 2015). If PST accumulation in $C$. gigas had a genetic and heritable basis, low PST accumulation oysters may be obtained by selective breeding. Nevertheless, such a selection would imply the selection of oysters also presenting a low filtration activity that might be associated with a low growth potential thus increasing the production time. Oyster farmers try to reduce production times by working with fast-growing oysters (i.e. triploids, selected fastgrowing families). It is likely that such a selection would also select for oysters presenting high clearance 

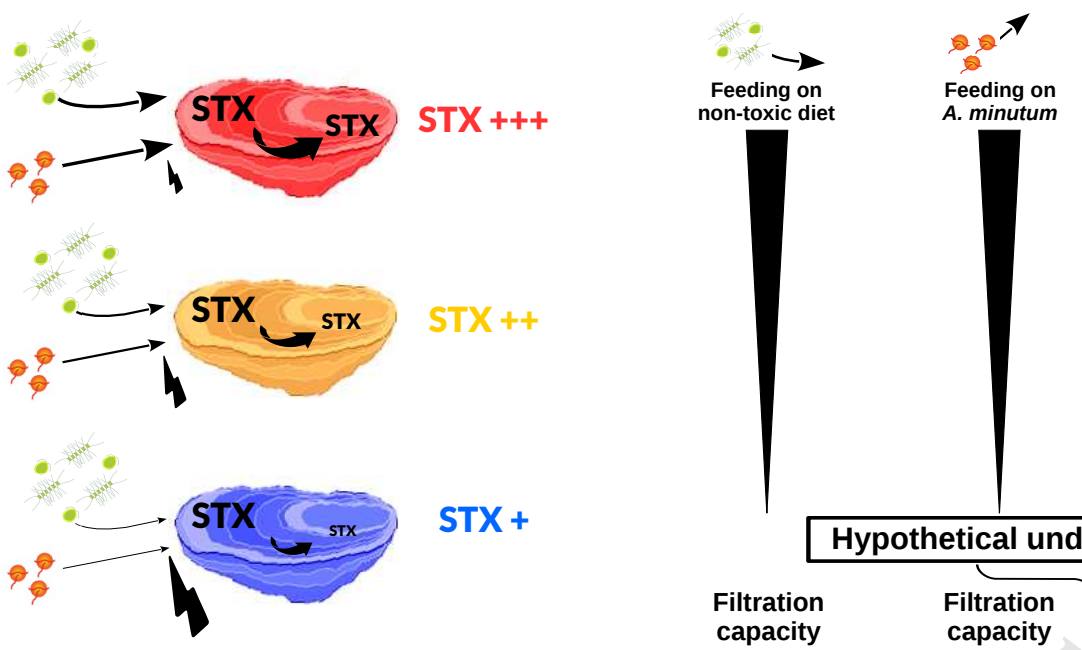

A. minutum
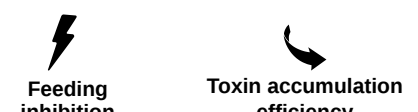

inhibition

efficiency

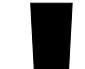

|

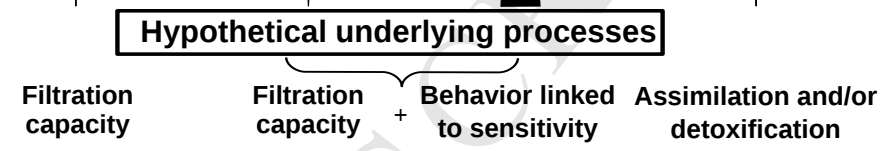

Figure 7: Scheme showing the three different accumulation "phenotypes" of oysters (red: high accumulation; yellow: intermediate accumulation; blue: low accumulation) identified in this study, their level of feeding on non-toxic and toxic algae, feeding inhibition when exposed to toxic algae and toxin accumulation efficiency. Hypothetical processes explaining these observations are also indicated. Note that STX refers to the saxitoxin and its derivatives.

rates and subsequently high PST accumulation potential. In both cases selection might thus not be beneficial for aquaculture.

This study provides new insights to improve sampling and analysis methodology used by national networks for phytoplankton monitoring (e.g. REPHY in France). Indeed, to properly consider the actual accumulation of oysters in the field, the sample size (number of oysters) should take into account the high inter-individual variability in accumulation. Because of this high variability, measurements of toxin concentration in oyster pools should be handled with care.

\section{Conclusion}

This study clearly highlights the contribution of feeding in toxin accumulation of oysters. Indeed, $78 \%$ of the inter-individual variability in toxin accumulation can be explained by the oyster filtration behavior during the exposure to A. minutum. Even if all the observed oysters exhibited the same primary response to this harmful algae (i.e. strong to total inhibition of filtration activity) they differed in their level of filtration recovery. Our results show that this behavior is connected to the filtration capacity, since oysters filtering the most on non-toxic algae were also the ones filtering the most on A. minutum. The present study cannot conclude on the underlying mechanisms leading to this inter-individual variability; however, it allows to link 
those ones to different phenotypes. As summarized in Fig. 7, three phenotypes could thus be observed which differed in (1) the filtration before and during exposure to A. minutum, (2) the clearance rate inhibition, (3) the toxin accumulation efficiency. Moreover, in each of these processes, clusters responded following the same gradation; oysters from the high accumulation cluster, for example, showed high filtration on both non-toxic algae and A. minutum (1), a low clearance rate inhibition (2), and a high toxin accumulation efficiency (3).

\section{Acknowledgements}

We are warmly grateful to Bruno Petton at the Ifremer experimental facilities in Argenton for providing SPF oysters, and also Jacqueline Le Grand and Dominique Ratiskol for producing the non-toxic algae. We also thank Loann Gissat, Isabelle Quéau and Mélaine Gourault for their technical help.

This study was carried out with the financial support of the French National Research Agency (ANR) "ACCUTOX" project (ANR-13-CESA-0019 2013-2017). This work is part of a PhD project supported by the "Laboratoire d'Exellence" LabexMer (ANR-10-LABX-19) and co-founded by a grant from the French government under the program "Investissement d'Avenir", and by a grant of the Regional Council of Brittany.

\section{References}

Aguirre-Velarde, A., Jean, F., Thouzeau, G., Flye-Sainte-Marie, J., 2018. Feeding behaviour and growth of the Peruvian scallop (Argopecten purpuratus) under daily cyclic hypoxia conditions. J. Sea Res. 131, 85-94.

Anderson, D. M., Alpermann, T. J., Cembella, A. D., Collos, Y., Masseret, E., Montresor, M., 2012. The globally distributed genus Alexandrium: multifaceted roles in marine ecosystems and impacts on human health. Harmful Algae 14, 10-35.

Anderson, D. M., Glibert, P. M., Burkholder, J. M., 2002. Harmful algal blooms and eutrophication: nutrient sources, composition, and consequences. Estuaries 25 (4), 704-726.

Bayne, B., Hawkins, A., Navarro, E., 1987. Feeding and digestion by the mussel Mytilus edulis L.(Bivalvia: Mollusca) in mixtures of silt and algal cells at low concentrations. J. Exp. Mar. Biol. Ecol. 111 (1), 1-22.

Bond, R., Medcof, J., 1958. Epidemic shellfish poisoning in New Brunswick, 1957. Can. Medic. Assoc. J. 79 (1), 19.

Bougrier, S., Lassus, P., Bardouil, M., Masselin, P., Truquet, P., 2003. Paralytic shellfish poison accumulation yields and feeding time activity in the Pacific oyster (Crassostrea gigas) and king scallop (Pecten maximus). Aquat. Living Resour. 16 (4), $347-$ 352.

Boullot, F., 2017. Implication des canaux sodium voltage-dépendant dans la réponse aux toxines chez Crassostrea gigas : le cas des phycotoxines paralysantes. Ph.D. thesis, Université de Bretagne Occidentale.

Bricelj, V., Lee, J., Cembella, A., 1991. Influence of dinoflagellate cell toxicity on uptake and loss of paralytic shellfish toxins in the northern quahog Mercenaria mercenaria. Mar. Ecol. Prog. Ser. 74, 33-46. 
Bricelj, V., Lee, J., Cembella, A., Anderson, D., 1990. Uptake kinetics of paralytic shellfish toxins from the dinoflagellate Alexandrium fundyense in the mussel Mytilus edulis. Mar. Ecol. Prog. Ser. 63 (2), 177-188.

Bricelj, V. M., Cembella, A., Laby, D., Shumway, S. E., Cucci, T. L., 1996. Comparative physiological and behavioral responses to PSP toxins in two bivalve molluscs, the softshell clam, Mya arenaria, and surfclam, Spisula solidissima. Harmful and Toxic Algal Blooms, Intergov. Oceanogr. Comm. of UNESCO, Paris, Yasumoto, T. Oshima, Y., Fukuyo, Y.(Eds.), 405-408.

Bricelj, V. M., Connell, L., Konoki, K., MacQuarrie, S. P., Scheuer, T., Catterall, W. A., Trainer, V. L., 2005. Sodium channel mutation leading to saxitoxin resistance in clams increases risk of PSP. Nature 434 (7034), 763-767.

Bricelj, V. M., Shumway, S. E., 1998. Paralytic shellfish toxins in bivalve molluscs: occurrence, transfer kinetics, and biotransformation. Rev. Fish. Sci. 6 (4), 315-383.

Buestel, D., Ropert, M., Prou, J., Goulletquer, P., 2009. History, status, and future of oyster culture in France. J. Sea Res. 28 (4), $813-820$.

Cembella, A. D., Shumway, S. E., Larocque, R., 1994. Sequestering and putative biotransformation of paralytic shellfish toxins by the sea scallop Placopecten magellanicus: seasonal and spatial scales in natural populations. J. Exp. Mar. Biol. Ecol. 180 (1), $1-22$.

Contreras, A. M., Marsden, I. D., Munro, M. H., 2012. Effects of short-term exposure to paralytic shellfish toxins on clearance rates and toxin uptake in five species of New Zealand bivalve. Mar. Freshw. Res. 63 (2), 166-174.

Dupuy, J., Sparks, A., 1968. Gonyaulax washingtonensis, its relationship to Mytilus californianus and Crassostrea gigas as a source of paralytic shellfish toxin in Sequim Bay, Washington. In: Proceedings of the National Shellfish Association. Vol. 58.

FAO, 2015. Fisheries and Aquaculture Information and Statistics Service, Global Production Statistics 1950-2013. Accessed: June $16,2016$.

URL http://www.fao.org/fishery/statistics/global-production/query/fr

Flye-Sainte-Marie, J., Jean, F., Paillard, C., Ford, S., Powell, E., Hofmann, E., Klinck, J., 2007. Ecophysiological dynamic model of individual growth of Ruditapes philippinarum. Aquaculture 266 (1), 130-143.

Gainey, L., Shumway, S., Shumway, S., 1988. A compendium of the responses of bivalve molluscs to toxic dinoflagellates. J. Shellfish Res. 7 (4), 623-628.

Gobler, C. J., Doherty, O. M., Hattenrath-Lehmann, T. K., Griffith, A. W., Kang, Y., Litaker, R. W., 2017. Ocean warming since 1982 has expanded the niche of toxic algal blooms in the North Atlantic and North Pacific oceans. Proc. Natl. Acad. Sci. 114 (19), 4975-4980.

Goulletquer, P., Soletchnik, P., Le Moine, O., Razet, D., Geairon, P., Faury, N., 1998. Summer mortality of the Pacific cupped oyster Crassostrea gigas in the Bay of Marennes-Oleron (France). In: CIEM Conseil International pour l'Exploration de la Mer.

Grizel, H., Héral, M., 1991. Introduction into France of the Japanese oyster (Crassostrea gigas). ICES J. Mar. Sci. 47 (3), $399-403$.

Guéguen, M., Baron, R., Bardouil, M., Truquet, P., Haberkorn, H., Lassus, P., Barillé, L., Amzil, Z., 2011. Modelling of paralytic shellfish toxin biotransformations in the course of Crassostrea gigas detoxification kinetics. Ecol. Model. 222 (18), $3394-3402$.

Guillard, R., Hargraves, P., 1993. Stichochrysis immobilis is a diatom, not a chrysophyte. Phycologia 32 (3), $234-236$.

Haberkorn, H., Tran, D., Massabuau, J.-C., Ciret, P., Savar, V., Soudant, P., 2011. Relationship between valve activity, microalgae concentration in the water and toxin accumulation in the digestive gland of the Pacific oyster Crassostrea gigas exposed to Alexandrium minutum. Mar. Pollut. Bull. 62 (6), 1191-1197. 
Hegaret, H., Wikfors, G. H., Shumway, S. E., 2007. Diverse feeding responses of five species of bivalve mollusc when exposed to three species of harmful algae. J. Shellfish Res. 26 (2), 549-559.

Hégaret, H., Wikfors, G. H., Soudant, P., Lambert, C., Shumway, S. E., Bérard, J. B., Lassus, P., 2007. Toxic dinoflagellates (Alexandrium fundyense and A. catenella) have minimal apparent effects on oyster hemocytes. Mar. Biol. 152 (2), $441-447$.

Hildreth, D., Crisp, D., 1976. A corrected formula for calculation of filtration rate of bivalve molluscs in an experimental flowing system. J. Mar. Biol. Assoc. UK 56 (01), 111-120.

Hoagland, P., Scatasta, S., 2006. The economic effects of harmful algal blooms. In: Ecology of harmful algae. Springer, pp. $391-402$.

Jørgensen, C. B., 1996. Bivalve filter feeding revisited. Mar. Ecol. Prog. Ser. 142, 287-302.

Kontis, K. J., Goldin, A. L., 1993. Site-directed mutagenesis of the putative pore region of the rat IIA sodium channel. Mol. Pharmacol. 43 (4), 635-644.

Kwong, R. W., Wang, W.-X., Lam, P. K., Yu, P. K., 2006. The uptake, distribution and elimination of paralytic shellfish toxins in mussels and fish exposed to toxic dinoflagellates. Aquat. Toxicol. 80 (1), $82-91$.

Laabir, M., Amzil, Z., Lassus, P., Masseret, E., Tapilatu, Y., De Vargas, R., Grzebyk, D., 2007. Viability, growth and toxicity of Alexandrium catenella and Alexandrium minutum (Dinophyceae) following ingestion and gut passage in the oyster Crassostrea gigas. Aquat. Living Resour. 20 (1), 51-57.

Lassudrie, M., Soudant, P., Nicolas, J.-L., Fabioux, C., Lambert, C., Miner, P., Le Grand, J., Petton, B., Hégaret, H., 2015a. Interaction between toxic dinoflagellate Alexandrium catenella exposure and disease associated with herpesvirus OsHV-1 $\mu$ var in Pacific oyster spat Crassostrea gigas. Harmful Algae 45, 53-61.

Lassudrie, M., Wikfors, G. H., Sunila, I., Alix, J. H., Dixon, M. S., Combot, D., Soudant, P., Fabioux, C., Hégaret, H., 2015b. Physiological and pathological changes in the eastern oyster Crassostrea virginica infested with the trematode Bucephalus sp. and exposed to the toxic dinoflagellate Alexandrium fundyense. J. Invertebr. Pathol. 126, 51-63.

Lassus, P., Amzil, Z., Baron, R., Séchet, V., Barillé, L., Abadie, E., Bardouil, M., Sibat, M., Truquet, P., Bérard, J.-B., 2007. Modelling the accumulation of PSP toxins in Thau lagoon oysters (Crassostrea gigas) from trials using mixed cultures of Alexandrium catenella and Thalassiosira weissflogii. Aquat. Living Resour. 20 (01), 59-67.

Lassus, P., Bardouil, M., Beliaeff, B., Masselin, P., Naviner, M., Truquet, P., 1999. Effect of a continuous supply of the toxic dinoflagellate Alexandrium minutum Halim on the feeding behavior of the Pacific oyster (Crassostrea gigas Thunberg). J. Sea Res. 18 (1), 211-216.

Lassus, P., Baron, R., Garen, P., Truquet, P., Masselin, P., Bardouil, M., Leguay, D., Amzil, Z., 2004. Paralytic shellfish poison outbreaks in the Penze estuary: Environmental factors affecting toxin uptake in the oyster, Crassostrea gigas. Aquat. Living Resour. 17 (2), 207-214.

Legendre, P., 2014. Imodel2: Model II Regression. R package version 1.7-2.

URL https://CRAN.R-project.org/package=lmodel2

Leverone, J. R., Shumway, S. E., Blake, N. J., 2007. Comparative effects of the toxic dinoflagellate Karenia brevis on clearance rates in juveniles of four bivalve molluscs from Florida, USA. Toxicon 49 (5), 634-645.

Mafra, L. L., Bricelj, V. M., Fennel, K., 2010. Domoic acid uptake and elimination kinetics in oysters and mussels in relation to body size and anatomical distribution of toxin. Aquat. Toxicol. 100 (1), 17-29.

Mafra, L. L., Bricelj, V. M., Ward, J. E., 2009. Mechanisms contributing to low domoic acid uptake by oysters feeding on Pseudo- 
nitzschia cells. II. Selective rejection. Aquat. Biol. 6, 213-226.

Marsden, I. D., Contreras, A. M., MacKenzie, L., Munro, M. H., 2015. A comparison of the physiological responses, behaviour and biotransformation of paralytic shellfish poisoning toxins in a surf-clam (Paphies donacina) and the green-lipped mussel (Perna canaliculus). Mar. Freshw. Res. 67 (8), 1163-1174.

Marsden, I. D., Shumway, S. E., 1993. The effect of a toxic dinoflagellate (Alexandrium tamarense) on the oxygen uptake of juvenile filter-feeding bivalve molluscs. Comp. Biochem. Physiol. Part A 106 (4), 769-773.

Mat, A., Klopp, C., Payton, L., Jeziorski, C., Chalopin, M., Amzil, Z., Tran, D., Hégaret, H., Soudant, P., Fabioux, C., Arnaud, H., in prep. Paralytic shellfish toxins load prediction by gene expression in oysters exposed to Alexandrium minutum.

Mat, A. M., Haberkorn, H., Bourdineaud, J.-P., Massabuau, J.-C., Tran, D., 2013. Genetic and genotoxic impacts in the oyster Crassostrea gigas exposed to the harmful alga Alexandrium minutum. Aquat. Toxicol. 140, 458-465.

McFarren, E. F., Schafer, M. L., Campbell, J. E., Lewis, K. H., Jensen, E. T., Schantz, E. J., 1961. Public health significance of paralytic shellfish poison. Adv. Food Res. 10, 135-179.

Medler, S., Silverman, H., 2001. Muscular alteration of gill geometry in vitro: implications for bivalve pumping processes. Biol. Bull. 200 (1), 77-86.

Moore, S. K., Trainer, V. L., Mantua, N. J., Parker, M. S., Laws, E. A., Backer, L. C., Fleming, L. E., 2008. Impacts of climate variability and future climate change on harmful algal blooms and human health. Environ. Health 7 (2), S4.

Moroño, A., Franco, J., Miranda, M., Reyero, M. I., Blanco, J., 2001. The effect of mussel size, temperature, seston volume, food quality and volume-specific toxin concentration on the uptake rate of PSP toxins by mussels (Mytilus galloprovincialis Lmk). J. Exp. Mar. Biol. Ecol. 257 (1), 117-132.

Navarro, J. M., Contreras, A. M., 2010. An integrative response by Mytilus chilensis to the toxic dinoflagellate Alexandrium catenella. Mar. Biol. 157 (9), 1967-1974.

Nisbet, I. C., 1983. Paralytic shellfish poisoning: effects on breeding terns. Condor 85 (3), 338-345.

Persich, G. R., Kulis, D. M., Lilly, E. L., Anderson, D. M., Garcia, V. M., 2006. Probable origin and toxin profile of Alexandrium tamarense (Lebour) Balech from southern Brazil. Harmful Algae 5 (1), 36-44.

Petton, B., Bruto, M., James, A., Labreuche, Y., Alunno-Bruscia, M., Le Roux, F., 2015. Crassostrea gigas mortality in France: the usual suspect, a herpes virus, may not be the killer in this polymicrobial opportunistic disease. Front. Microbiol. 6:686.

Petton, B., Pernet, F., Robert, R., Boudry, P., 2013. Temperature influence on pathogen transmission and subsequent mortalities in juvenile Pacific oysters Crassostrea gigas. Aquac. Environ. Inter. 3, 257-273.

Pino-Querido, A., Álvarez-Castro, J. M., Guerra-Varela, J., Toro, M. A., Vera, M., Pardo, B. G., Fuentes, J., Blanco, J., Martinez, P., 2015. Heritability estimation for okadaic acid algal toxin accumulation, mantle color and growth traits in Mediterranean mussel (Mytilus galloprovincialis). Aquaculture 440, 32-39.

Pouvreau, S., Jonquières, G., Buestel, D., 1999. Filtration by the pearl oyster, Pinctada margaritifera, under conditions of low seston load and small particle size in a tropical lagoon habitat. Aquaculture 176 (3), 295-314.

R Core Team, 2016. R: A Language and Environment for Statistical Computing. R Found. Stat. Comput., Vienna, Austria.

URL https://www.R-project.org/

Rahel, F. J., Olden, J. D., 2008. Assessing the effects of climate change on aquatic invasive species. Conserv. Biol. 22 (3), $521-533$.

REPHY, 2015. Bulletins d'information et d'alerte - Rephy info toxines. Accessed: June 14, 2017.

URL https://envlit-alerte.ifremer.fr/accueil 
Sagou, R., Amanhir, R., Taleb, H., Vale, P., Blaghen, M., Loutfi, M., 2005. Comparative study on differential accumulation of PSP toxins between cockle (Acanthocardia tuberculatum) and sweet clam (Callista chione). Toxicon 46 (6), 612-618.

Savina, M., Pouvreau, S., 2004. A comparative ecophysiological study of two infaunal filter-feeding bivalves: Paphia rhombordes and Glycymeris glycymeris. Aquaculture 239 (1), 289-306.

Shumway, S., Cucci, T., Gainey, L., Yentsch, C., 1985. A preliminary study of the behavioral and physiological effects of Gonyaulax tamarensis on bivalve molluscs. Toxic Dinoflag. N-Y: Elsevier Sci. Publ., 389-394.

Shumway, S. E., Cucci, T. L., 1987. The effects of the toxic dinoflagellate Protogonyaulax tamarensis on the feeding and behaviour of bivalve molluscs. Aquat. Toxicol. 10 (1), 9-27.

Stachowicz, J. J., Terwin, J. R., Whitlatch, R. B., Osman, R. W., 2002. Linking climate change and biological invasions: ocean warming facilitates nonindigenous species invasions. Proc. Natl. Acad. Sci. 99 (24), 15497-15500.

Tran, D., Haberkorn, H., Soudant, P., Ciret, P., Massabuau, J.-C., 2010. Behavioral responses of Crassostrea gigas exposed to the harmful algae Alexandrium minutum. Aquaculture 298 (3), 338-345.

Twarog, B. M., Hidaka, T., Yamaguchi, H., 1972. Resistance to tetrodotoxin and saxitoxin in nerves of bivalve molluscs: A possible correlation with paralytic shellfish poisoning. Toxicon 10 (3), 273-278.

Van Dolah, F. M., 2000. Marine algal toxins: origins, health effects, and their increased occurrence. Environ. Health Perspect. 108 (Suppl 1), 133.

Walne, P. R., et al., 1970. Studies on the food value of nineteen genera of algae to juvenile bivalves of the genera Ostrea, Crassostrea, Mercenaria and Mytilus. Fish. Invest. Ser. 226 (5).

Ward, J., Levinton, J., Shumway, S., Cucci, T., 1998. Particle sorting in bivalves: in vivo determination of the pallial organs of selection. Mar. Biol. 131 (2), 283-292.

Ward, J. E., Levinton, J. S., Shumway, S. E., 2003. Influence of diet on pre-ingestive particle processing in bivalves: I: transport velocities on the ctenidium. J. Exp. Mar. Biol. Ecol. 293 (2), 129-149.

Wildish, D., Lassus, P., Martin, J., Saulnier, A., Bardouil, M., 1998. Effect of the PSP-causing dinoflagellate, Alexandrium sp. on the initial feeding response of Crassostrea gigas. Aquat. Living Resour. 11 (01), 35-43.

Wisessang, S., Ogata, T., Kodama, M., Fukuyo, Y., Ishimaru, T., Saitanu, K., Yongvanich, T., Piyakarnchana, T., 1991. Accumulation of paralytic shellfish toxins by green mussel Perna viridis by feeding on cultured cells of Alexandrium cohorticula isolated from the gulf of Thailand. Nippon Suisan Gakkaishi 57 (1), 127-131. 